\title{
Odhad vývoje budoucích odběrů vody v ČR
}

\section{LIBOR ANSORGE, JIŘí DLABAL}

Klíčová slova: budoucí odběry vody - scénáře vývoje - vodohospodářská bilance

\section{SOUHRN}

V předloženém článku jsou shrnuty závěry projektu TD020113, jehož cílem bylo stanovení možných budoucích potřeb vody v časovém horizontu 2030 až 2050 V rámci projektu TD 020113 byly analyzovány čtyři možné scénáře vývoje české společnosti. Článek navazuje na predchozí publikované výsledky zabývající se pouze sektorem veřejných vodovodů [1] a doplňuje je o další zpracované sektory (energetika a živočišná výroba). Odběry pro průmysl, rostlinnou výrobu a ostatní odběry jsou pak odhadnuty na základě současných trendů.

\section{ÚVOD}

Existující studie dopadů klimatické změny jasně formulují trendy a závěry týkající se poklesu dostupnosti vodních zdrojů v následujících desetiletích. Ke stejným závěrưm dochází studie jak české, tak evropské či globální. Kvantifikace dostupnosti vodních zdrojů je predmětem mnoha studií a výzkumných projektů jak v České republice, tak na celém světě. Z českých výstupů v posledních dvou letech Ize pro ilustraci jmenovat např. materiál zpracovaný pro MŽP [2] či studie VúV TGM [3-5]. České materiály se, snad vlivem dlouhodobého poklesu odběrů povrchových a podzemních vod $v$ uplynulých 35 letech, kdy maximálních odběrů ve výši 3,52 mld. $\mathrm{m}^{3}$.rok-1 bylo dosaženo v roce 1983 [6] (obr. 1), kvantifikací budoucích odběrů ve výhledu 15, 20 a více let prakticky nezabývají a soustředují se na problematiku kvantifikace hydrologické bilance. Strategické rozhodování v sektoru vodního hospodářství i řešení vodohospodářské bilance ve střednědobém a dlouhodobém výhledu často spoléhá na porovnávání současných odběrů, či dokonce současných povolených odběrů s budoucími zdroji. Že taková srovnání mohou vést k ošidným závěrům je jasné, pokud si uvědomíme, jak dramatické změny v odběrech mohou nastat vlivem změněných klimatických (což je předpokládaná budoucnost) či socioekonomických podmínek (což dokládá zejména vývoj odběrů v 90. letech minulého století). $\checkmark$ rámci zmiňovaného projektu TD020113 jsme se pokusili uvedenou skutečnost alespoň částečně napravit a připravit odhad potřeb vody na základě scénářu socioekonomických podmínek v časovém horizontu 2030 až 2050.

\section{ODBĚRY V UPLYNULÝCH 35 LETECH}

\section{Sektor veřejných vodovodů}

Zatímco v 80. letech minulého století (s výjimkou roku 1984) docházelo prakticky k plynulému nárůstu odběrů pro sektor veřejných vodovodů až na úroveň $1,27 \mathrm{mld}$. $\mathrm{m}^{3} \cdot$ rok $^{-1}$ (obr. 2a), tak po roce 1989 dochází k plynulému poklesu

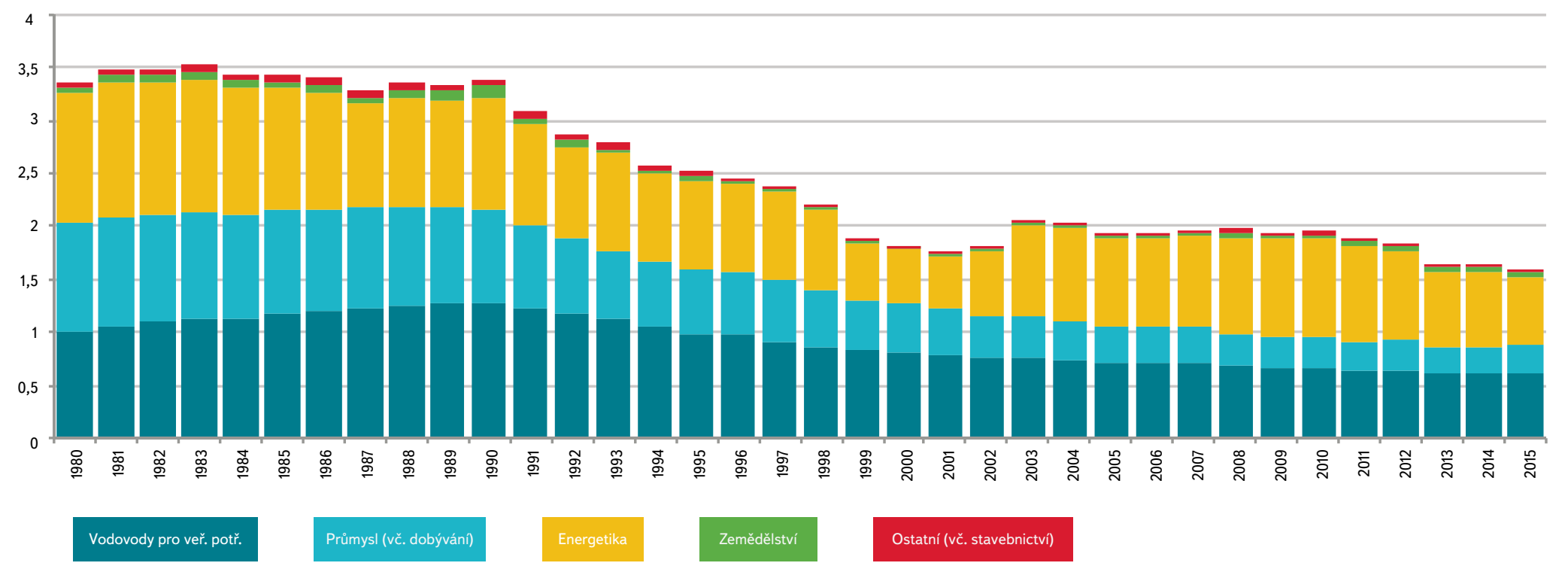

Obr. 1. Odběry povrchových a podzemních vod v ČR v letech 1980-2015 (zdroj dat: MZe a MŽP [6])

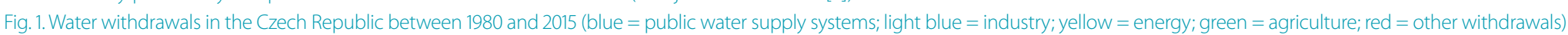


(s výjimkou let 2006, 2012 a 2015) až na úroveň 602 mil. m³.rok-1 v roce 2014. Výjimky v trendech v letech 1984, 2006 a 2012 jsou statisticky nevýznamné (méně jak 0,4\%). Proti tomu změna v roce 2015 dosáhla hodnoty 1,79\% ve srovnání s rokem předchozím a mohlo by tak jít o změnu trendu, což však bude možno posoudit až v následujících letech.

\section{Sektor energetiky}

Odběry pro sektor energetiky dosáhly maxima v roce 1981 ve výši 1,284 mld. m³.rok¹ (obr. 2b) a až do roku 2001 Ize sledovat klesající trend odběrů až na úroveň 502 mil. $\mathrm{m}^{3}$.rok . Nárůst odběrů pro sektor energetiky je spojen s uváděním Jaderné elektrárny Temelín do provozu v letech 2001 a 2002. Desetiletí 2003-2012 pak vykazuje odběry kolísající v intervalu 828 mil. až $942 \mathrm{mil}^{3} \mathrm{~m}^{3} \cdot$ rok $^{-1}$ následované postupným poklesem na hodnotu $613 \mathrm{mil}^{\mathrm{m}} \mathrm{m}^{3} \cdot \mathrm{rok}^{-1} \mathrm{v}$ roce 2015. S ohledem na plánované i neplánované odstávky obou jaderných elektráren $v$ uplynulém roce Ize předpokládat pokračování poklesu v odběrech celého sektoru i v roce 2016.

\section{Sektor průmyslu}

Odběry pro sektor průmyslu dosáhly maxima v roce 1981 na úrovni 1,03 mld. $\mathrm{m}^{3} \cdot$ rok $^{-1}$ a minima v roce 2013 na úrovni 248,5 mil. $\mathrm{m}^{3} \cdot$ rok $^{-1}$ (obr. 2c). Celkově lze odběry pro sektor průmyslu charakterizovat klesajícím trendem, který byl akcelerován po roce 1989. V období 2009 až 2015 však dochází k výrazné ztrátě dynamiky poklesu odběrů a spíše stagnaci odběrů v rozpětí 250 až $290 \mathrm{mil}^{3} \mathrm{~m}^{3}$.rok 1 .

\section{Sektor zemědělství}

Odběry pro sektor zemědělství v uplynulých 35 letech Ize rozdělit do tři charakteristických období (obr. 2d). V období 1980-1990 není patrný jednoznačný trend a odběry kolísají mezi 44 až 110 mil. m³.rok-1 kdy v roce 1990 je dosaženo absolutního maxima za celých 35 let. V období 1990 až 1998 dochází k plynulému poklesu až na úroveň 7,4 mil. $\mathrm{m}^{3}$.rok ${ }^{-1}$ a po tomto období naopak dochází ke změně trendu a k postupnému nárůstu odběrů až na úroveň 54 mil. m³.rok'.

\section{Sektor ostatních odběrů}

Odběry v sektoru ostatní (včetně stavebnictví) tvoří zanedbatelnou část celkových odběrů (obr. 2e). Lze je $v$ uplynulých 35 letech rozdělit na dvě samostatná období. V letech 1980-1996 dochází ke kolísání hodnoty odběrů kolem 60 mil. m³.rok-1, pak následuje pokles k cca 10 mil. m³.rok ${ }^{-1}$ v letech 1997-2002 a následný postupný nárůst až do roku 2008. V roce 2008 prechází Český statistický úřad z nomenklatury "OKEČ" na nomenklaturu "CZ-NACE". Určité implementační zmatky spojené $s$ touto změnou se pravděpodobně projevily v „odlehlé" hodnotě odběrů v roce 2008 , která se v ostatních sektorech neprojevila tak významně. Posledním obdobím je pak období 2009 až 2015, kdy opět dochází ke kolísání hodnoty odběrů (tj. stagnaci) okolo hodnoty 26 mil. m³.rok-1.

\section{METODIKA A VSTUPNÍ DATA}

Řešení projektu TD020113 vycházelo z principů DPSIR konceptu [7, 8] a z aplikace Story and Simulation prístupu $[9,10]$. Story and Simulation přístup spočivá $\checkmark$ kombinaci popisných scénářů budoucího vývoje s modelovacím aparátem pro kvantifikaci zvolených ukazatelů. Pro část projektu zabývající se matematickým modelováním byl zvolen prístup postavený na využití statistických
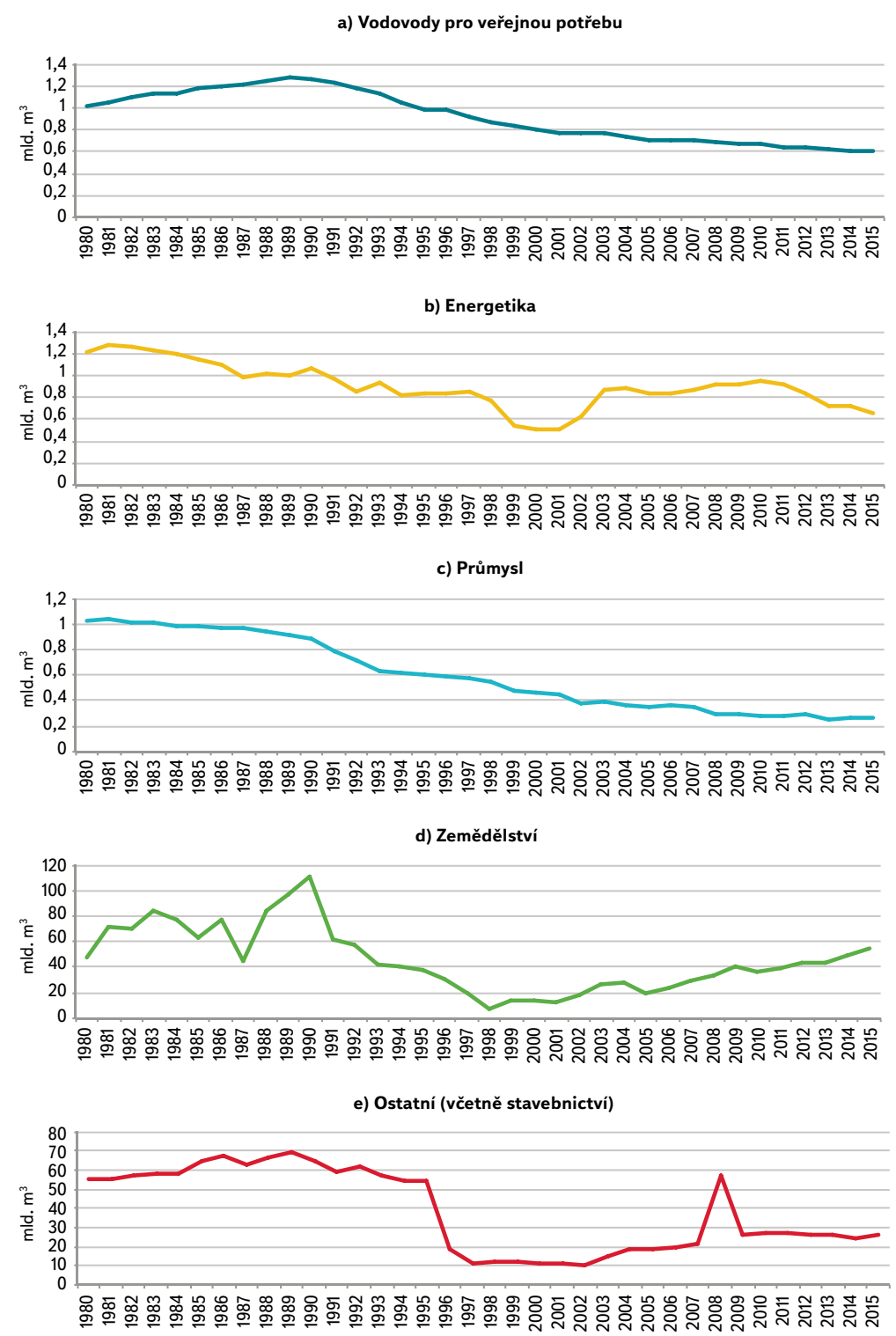

Obr. 2. Průběh odběrů v sektorech národního hospodářství ČR v období 1980-2015 Fig. 2. Water withdrawals in the individual sectors in the Czech Republic between 1980 and 2015 (blue = public supply systems; light blue = industry; yellow = energy; green = agriculture; red $=$ other withdrawals)

modelů. Tento přístup je využíván zejména v ekonometrii a zde byl použit pro otestování jeho aplikovatelnosti na problémy spojené s užíváním vod. Řešení se soustředilo na sektory veřejných vodovodů a energetiky, které jsou dominantní v odběrech vody v České republice (dohromady okolo $80 \%$ odběrů za posledních deset let), a sektor zemědělství, který je sice z pohledu evidovaných odběrů bezvýznamný (méně než 3,4\%), ale z hlediska budoucího vývoje je jedním z nejcitlivějších na dopady klimatické změny.

Jedním z výsledků projektu je metodický materiál [11], který je obecně využitelný při stanovování budoucích odběrů (potřeb) vody, ale i budoucích hodnot jiných environmentálních či socioekonomických ukazatelů. S ohledem na dostupnost vstupních dat bylo pro řešení zvoleno prostorové měřitko celé České republiky a data byla využivána v ročním časovém kroku. Pro řešení byla vybrána statistická data shromažd’ována podle české legislativy dostupná u Českého statistického úřadu, popř. v rámci resortních statistik a statistik vládních institucí (např. Energetický regulační úřad). Zejména pro sektor zemědělství 


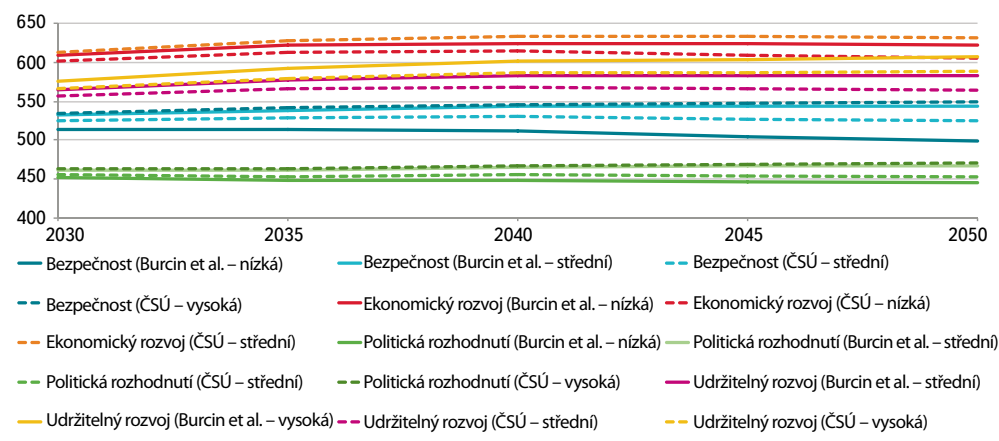

Obr. 3. Očekávaný vývoj odběrů pro sektor veřejných vodovodů při středních hodnotách hnacích sil pro rưzné demografické prognózy

Fig. 3. Estimation of water withdrawals in public water supply sector for different socio-economic scenarios and demographic prognosis

byla též využívána data profesních sdružení. Pro popis budoucího stavu české společnosti byly odvozeny čtyři scénáre:

1. Scénář preferující udržitelný rozvoj,

2. Scénář preferující politická rozhodnutí na ochranu životního prostředí,

3. Scénář preferující ekonomický rozvoj s omezením ochrany životního prostředí,

4. Scénář preferující bezpečnostní otázky a zajištění soběstačnosti v zásobování.

Obecný popis jednotlivých scénářu je uveden v prípadové studii [12], kde je též podrobněji popsán vývoj v sektoru veřejných vodovodů a energetiky, resp. $\checkmark$ disertační práci jednoho z autorů tohoto článku [13] pro sektor zemědělství. Pro kvantifikaci scénářu byly využity existující sektorové prognózy. Pro sektor energetiky to byla aktualizovaná Státní energetická koncepce [14, 15]. Pro popis demografického vývoje byly využity prognózy ČSú $[16,17]$ a prímo pro projekt TD020113 byla pracovníky Univerzity Karlovy zpracována demografická prognóza [18]. Pro popis hospodářského vývoje byly využity scénáře připravené pro aktualizaci státní energetické koncepce [15]. Jednotlivé sektorové prognózy byly pririrazeny vybraným scénárưm vývoje společnosti podle podobnosti předpokladů, ze kterých bylo při jejich sestavování vycházeno. V případě demografických a energetických prognóz bylo k jednotlivým scénárưm následně přirazeno i více prognóz. Pro sektor zemědělství byly ve spolupráci s pracovníky Ústavu zemědělské ekonomiky a informací kvantifikovány počty zvírat a osevní plochy hospodářských plodin pro jednotlivé scénáře vývoje společnosti.

\section{VÝSLEDKY}

\section{Sektor veřejných vodovodů}

Sektor veřejných vodovodů byl podrobně představen v samostatném článku [1]. Jako hlavní hnací síly byly zvoleny:

- počet obyvatel,

- ztráty vody v síti,

- podíl obyvatelstva napojeného na veřejné vodovody,

- specifická spotřeba domácností,

- ekonomická efektivita užití vody.

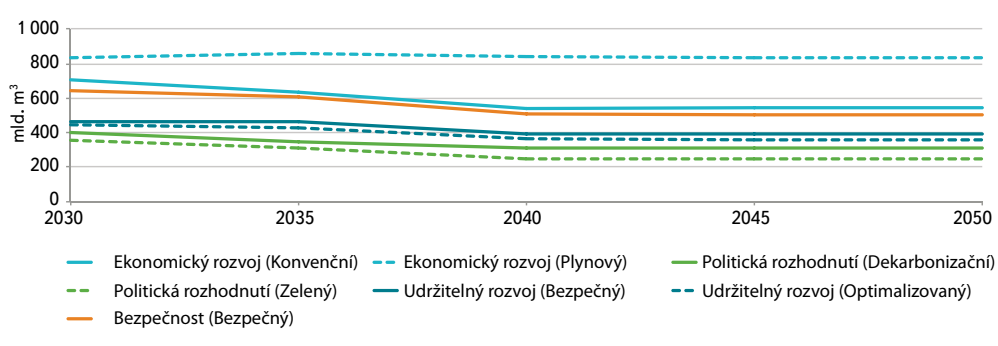

Obr. 4. Očekávaný vývoj odběrů pro sektor energetiky při středních hodnotách hnacích sil pro různé scénáře rozvoje energetické základny ČR

Fig. 4. Estimation of water withdrawals energy sector for different socio-economic scenarios and energy development scenarios

Přiřazením různých demografických prognóz $k$ jednotlivým scénářům vývoje vzniklo $3 \times 15$ možných trajektorií odběrů vod v sektoru veřejných vodovodů. Pro časový horizont 2030 až 2050 Ize při uvažování středních hodnot hnacích sil očekávat odběry v rozsahu 452 až 634 mil. m³.rok-1 (obr. 3), resp. 397 až 707 mil. m³.rok¹, při uvažování horních a dolních intervalů hodnot. Resp. jeden scénář předpokládá v porovnání se současností stagnaci až mírný nárůst odběrů, jeden scénář předpokládá mírný pokles až stagnaci a dva scénáře předpokládají pokles odběrů pro veřejné vodovody.

\section{Sektor energetiky}

Pro sektor energetiky je rozhodujícím limitem ukončení činnosti uhelných elektráren po roce 2030. Aktualizovaná Státní energetická koncepce [14] představuje šest možných scénářu budoucího vývoje české energetiky. Těchto šest energetických scénářu bylo prriřazeno ke čtyřem scénárưm vývoje společnosti podle podobnosti výchozích predpokladů pro odvození jednotlivých scénářu [12]. Pro sektor energetiky byly jako hnací síly zvoleny:

- struktura energetického mixu podle Státní energetické koncepce vyjádřená formou výroby v tepelných a jaderných elektrárnách,

- podíl tepelných elektráren s průtočným chlazením,

— technologický pokrok vyjádřený jako specifické spotřeby vody v tepelných a jaderných elektrárnách.

Vzhledem k situaci, kdy energie vyrobená v České republice je uplatňována na evropském trhu, nepředstavuje počet obyvatelstva České republiky významný faktor ovlivňující produkci energií v tuzemsku. Kalkulované hodnoty potřeb vody v období 2030 až 2050 postupně v jednotlivých scénárích klesají v závislosti na míre odstavování tepelných elektráren a nahrazováním jejich kapacity jinými technologiemi výroby elektrické energie (obr. 4). Pouze kombinace scénáre preferující ekonomický rozvoj společnosti a plynového scénáře rozvoje energetické základy České republiky předpokládá stabilní potřeby vody na úrovni 835 až 855 mil. $\mathrm{m}^{3} \cdot$ rok $^{-1}$, ostatní scénáře předpokládají postupný pokles

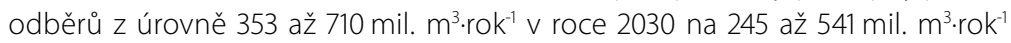
v roce 2050 (při uvažování středních hodnot intervalů hnacích sil použitých pro modelové rešení).

\section{Sektor zemědělství}

Sektor zemědělských odběrů je třeba rozdělit na rostlinnou a živočišnou výrobu. V prủběhu řešení projektu se ukázalo, že z důvodu nedostupnosti relevantních informací o předpokládané změně agroklimatických regionů [2] by připravené modelové řešení rostlinné výroby poskytlo výsledky, které s vysokou pravděpodobností nebudou odpovídat realitě v hodnoceném období cca poloviny 21. století. Řešení sektoru zemědělství se tak omezilo jen na živočišnou 


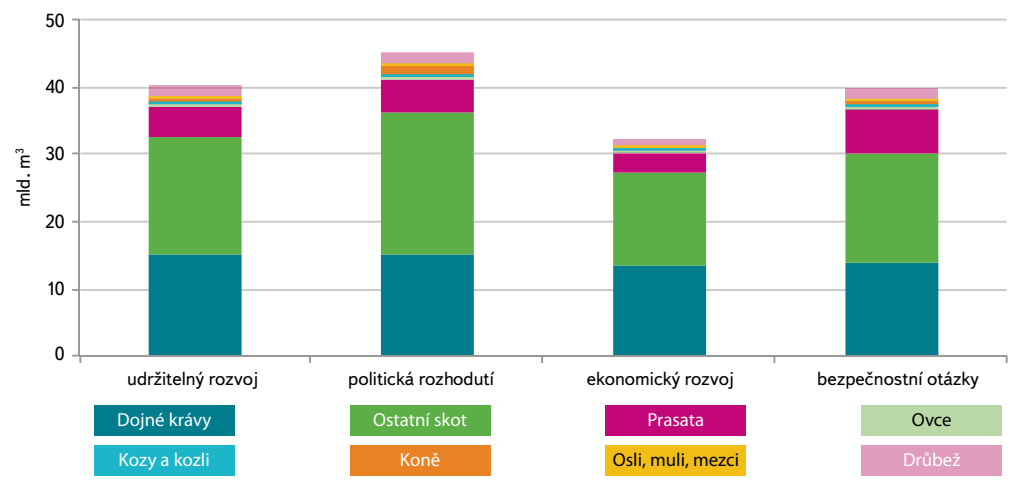

Obr. 5. Odhad potřeb vody pro živočišnou výrobu v období 2030 až 2050 Fig. 5. Estimation of water needs for livestock in period from 2030 to 2050 (dark blue = dairy cows; brown = other cattle; green = pigs; purple = sheep; light blue = goats; orange $=$ horses; yellow $=$ donkeys and mules; pink = poultry)

výrobu. V oblasti živočišné výroby byly ve spolupráci s pracovníky UZEI provedeny odhady počtu hospodářských zviŕat chovaných v České republice v podmínkách jednotlivých scénářu vývoje společnosti. S využitím hodnot specifických potřeb vody pro jednotlivé kategorie zvířat vycházejících z ČSN 755490 pro návrh stájových vodovodů byly stanoveny odhady potřeb vody v živočišné výrobě jak pro současnost, tak pro scénáře navržené v projektu.

Na rozdíl od sektorů veřejných vodovodů a energetiky nebyla kvantifikace potřeb pro živočišnou výrobu počitána v různých časových horizontech hodnoceného období 2030 až 2050, ale (s ohledem na evidentní nesoulad mezi hodnotami odběrů a odhady potřeb pro současnost) bylo provedeno pouze stanovení jedné hodnoty odhadu potřeb vody v živočišné výrobě pro každý scénář vývoje společnosti. Odhad potřeby vody v živočišné výrobě v období 2030 až 2050 se pohybuje mezi 32 až 45 mil. m³.rok ${ }^{-1}$ pro jednotlivé scénáre (obr.5). Odběry pro živočišnou výrobu se pohybovaly v letech 2001 až 2015 se skoro lineárním průběhem v rozpětí 7 až 12,5 mil. $\mathrm{m}^{3}$.rok ${ }^{-1} \mathrm{~s}$ jasným vzestupným trendem. Kalkulované potřeby vody v živočišné výrobě pro současnost činí 35 až 40 mil. $\mathrm{m}^{3} \cdot$ rok $^{-1}$ a přesahují $3 \times$ až $5 \times$ hodnoty odběrů pro živočišnou výrobu. Malá část z tohoto chybějícího množství je pokryta dodávkami vody do

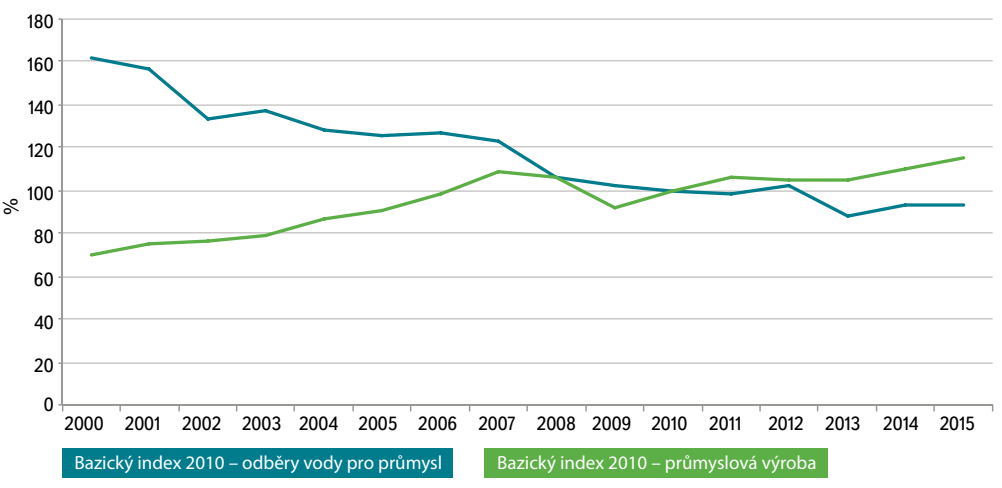

Obr. 6. Indexy odběrů vod pro průmysl a průmyslové výroby - hodnoty roku $2010=$ 100 \% (zdroj dat: Čsú a evidence odběrů a vypouštění)

Fig. 6. Index of water withdrawals for industry (blue colour) and index of industry production (brown colour) -2010 value $=100 \%$

zemědělství z veřejných vodovodů, které činily v letech 2004 až 2012 9,6 až 7,2 mil. $\mathrm{m}^{3} \cdot$ rok $^{-1} \mathrm{~s}$ naopak klesajícím trendem. Dochází tak k substituci dodávek do zemědělství z veřejných vodovodů prímými odběry z povrchových a podzemních vod. Hlavním důvodem pro tuto substituci je zejména rozdílná cena pitné a surové vody.

\section{Sektor průmyslu a sektor ostatních odběrů včetně stavebnictví}

Obdobně jako v mnoha jiných rozvinutých zemích došlo v České republice k tzv. „decouplingu“ [19] spotřeby vody a hospodářského výkonu ekonomiky, resp. průmyslového růstu, kdy i přes růst průmyslové produkce dochází k poklesům odběrů pro průmysl (obr. 6). Hlavními hnacími silami odběrů pro průmysl tak není samotná průmyslová produkce, ale technologický pokrok, legislativní a ekonomické podmínky spojené se zaváděním úsporných opatření. Prưmysl v České republice je však velmi různorodý a bylo by vhodné jej řešit po jednotlivých průmyslových odvětvích. $\vee$ projektu však nebyl pro takto podrobnou analýzu dostatek prostoru.

Tabulka 1. Odhad potřeb vody (odběrů vody) pro jednotlivé scénáre pro období 2030 až 2050

Table 1. Estimation of water needs (withdrawals) per individual scenarios for period 2030 and 2050

\section{Scénár̆}

Bezpečnostní otázky

Ekonomický rozvoj

Politická rozhodnutí

Udržitelný rozvoj

Sektor

[mil. $\left.\mathrm{m}^{3} \cdot \mathrm{rok}^{-1}\right]$

\begin{tabular}{lrrrr}
\hline Energetika & $504-645$ & $541-835$ & $245-399$ & $459-464$ \\
\hline Vě̌ejné vodovody & $505-548$ & $601-634-470$ & $556-604$ & $65-75$ \\
\hline Závlahy* & $65-75$ & $65-75$ & 45 & 45 \\
\hline Živočišná výroba** & 40 & 32 & 250 & 25 \\
\hline Průmysl* $^{*}$ & 250 & 250 & $\mathbf{2 5}$ & $\mathbf{1 0 7 6 - 1 2 6 4}$
\end{tabular}

* Pouze odhad na základě současných trendů, tyto sektory nebyly modelově řešeny.

** V tabulce jsou použity hodnoty kalkulovaného odhadu potřeb, nikoliv odhad odběrů uváděný v diskusní části článku. 
Sektor ostatních odběrů (včetně stavebnictví) nebyl v projektu TD020113 řešen z důvodu nedostupnosti dat a minimálního podílu tohoto sektoru na celkových odběrech vody, který činí obvykle 0,5 až $2 \%$ z celkových odběrů $\checkmark$ daném roce.

\section{DISKUSE}

Při řešení sektoru energetiky nebyl vzat v úvahu harmonogram očekávaného útlumu významných tepelných elektráren publikovaný až v průběhu roku 2016 [20]. Alternativou k vládním energetickým scénářum [14] jsou scénáře rozvoje elektroenergetiky připravené operátorem trhu s energiemi každoročně publikované v tzv. Zprávách o očekávané rovnováze [21]. Tyto podklady mohou vést $k$ dalšímu zpřesnění vývoje budoucích potřeb/odběrů vody pro sektor energetiky.

Proložení hodnot procentní změny odběrů v sektoru průmyslu oproti odběrům předchozího roku polynomickým trendem v Microsoft Excel naznačuje změnu trendu směrem ke kladným hodnotám při všech dostupných stupních polynomu (2 až 6). V nejbližším období tak Ize očekávat stagnaci, či dokonce růst odběrů pro průmysl. Pro hodnocené období 2030 až 2050 však nelze z existujících dat vyvozovat obdobné závěry.

V zemědělství Ize na základě současných znalostí jednoznačně předpokládat nárůst požadavků na zajištění zdrojů pro závlahy. Významným faktorem pro stanovení skutečných potřeb vody pro závlahy však bude posun agroklimatických oblastí a změny ve struktuře plodin v jednotlivých regionech České republiky [2]. V uplynulých 15. letech, ve kterých jsou informace o užití odebrané vody, se hodnoty odběrů využívaných pro závlahy pohybovaly v rozpětí 10 až 40 mil. $\mathrm{m}^{3} \cdot$ rok $^{-1} \mathrm{~s}$ jasným vzestupným trendem. Při pokračování dosavadního trendu bychom se kolem roku 2030 mohli dočkat odběrů kolem 65 až 75 mil. $\mathrm{m}^{3}$.rok . $^{-1}$ pro závlahy. Kolem roku 2050 se však již začnou výrazněji projevovat posuny agroklimatických výrobních oblastí a prostá predikce na základě současných trendů postrádá pro takto vzdálené období jakéhokoliv smyslu.

Při uvažování dalšího pokračování substituce drahé pitné vody za levnější surovou vodu bude docházet ke sbližování odběrů pro živočišnou výrobu s kalkulovanými potřebami vody. V období 2030 až 2050 tak Ize odhadnout odběry pro živočišnou výrobu na úrovni kolem 18 až 28 mil. $\mathrm{m}^{3} \cdot$ rok $^{-1}$.

Odběry pro průmysl budou velmi záviset na rozvoji či útlumu jednotlivých průmyslových odvětví v České republice. Pro období 2030 až 2050 je při současném vývoji a znalostech vhodné uvažovat spíše se stagnací odběrů okolo úrovně 250 mil. $\mathrm{m}^{3}$.rok ${ }^{-1}$ než s nějakou významnou změnou. Další výrazný pokles odběrů se jeví jako málo pravděpodobný. Naopak nárůst odběrů by mohl nastat v souvislosti s masivním růstem průmyslové produkce, nebo uvolněním environmentálních podmínek spolu se zlevněním vody.
Odhadujeme, že odběry v sektoru ostatních odběrů včetně stavebnictví zůstanou i ve výhledu 2030 až 2050 stabilní a budou se pohybovat na současné úrovni, tj. kolem 25 mil. m³.rok ${ }^{-1}$.

\section{ZÁVĚR}

V rámci projektu TD020113 byly řešeny čtyři scénáře vývoje české společnosti a k nim byly stanoveny očekávané potřeby vody pro časový horizont 2030 až 2050. V tomto časovém horizontu Ize očekávat značný pokles potřeb vody pro energetiku (3 ze 4 scénářů) a pravděpodobnou stagnaci (2 scénáře) či pokles (2 scénáře) odběrů pro veřejné vodovody. Dále byla kalkulována mírně zvýšená potřeba vody pro živočišnou produkci. Vzhledem k tomu, že v současnosti není př́má vazba mezi odběry pro živočišnou produkci a potřebami kalkulovanými na základě počtu chovaných zvírat a specifickými potřebami, Ize pouze provést odhad budoucích odběrů pro zemědělství na základě stávajících trendů a očekávaného vývoje. Pravděpodobně Ize však očekávat rostoucí odběry pro živočišnou výrobu. Kalkulace potřeb pro závlahy nebyla v projektu provedena z důvodu nedostatečných podkladů o změnách agroklimatických regionů. Odhady potřeb vody pro závlahy, provedené na základě aktuálních trendů, jsou tak vztaženy k roku 2030. V sektoru průmyslu i ostatních odběrů (včetně stavebnictví) očekáváme stagnaci odběrů.

V případě scénáře preferujícího bezpečnostní otázky jsou v období 2030 až 2050 odhadovány odběry na úrovni 1,389 až 1,583 mld. $\mathrm{m}^{3}$.rok-1 V prípadě scénáre preferujícího ekonomický rozvoj jsou odhadovány potřeby vody v období 2030 až 2050 na úrovni 1,514 až 1,851 mld. m³.rok¹. V prípadě scénáře preferujícího politická opatření na ochranu životního prostředí Ize očekávat pokles potřeb vody na úroveň 1,076 až 1,264 mld. $\mathrm{m}^{3} \cdot$ rok $^{-1}$ a $v$ prípadě scénáře preferujícího udržitelný rozvoj pak na úrovni 1,295 až 1,458 mld. $\mathrm{m}^{3} \cdot$ rok $^{-1}$ (tabulka 1).

\section{Poděkování}

Projekt Dopady socioekonomických změn ve společnosti na spotřebu vody byl řešen s finanční podporou Technologické agentury České republiky v rámci Programu na podporu aplikovaného společenskovědního výzkumu a experimentálního vývoje Omega.

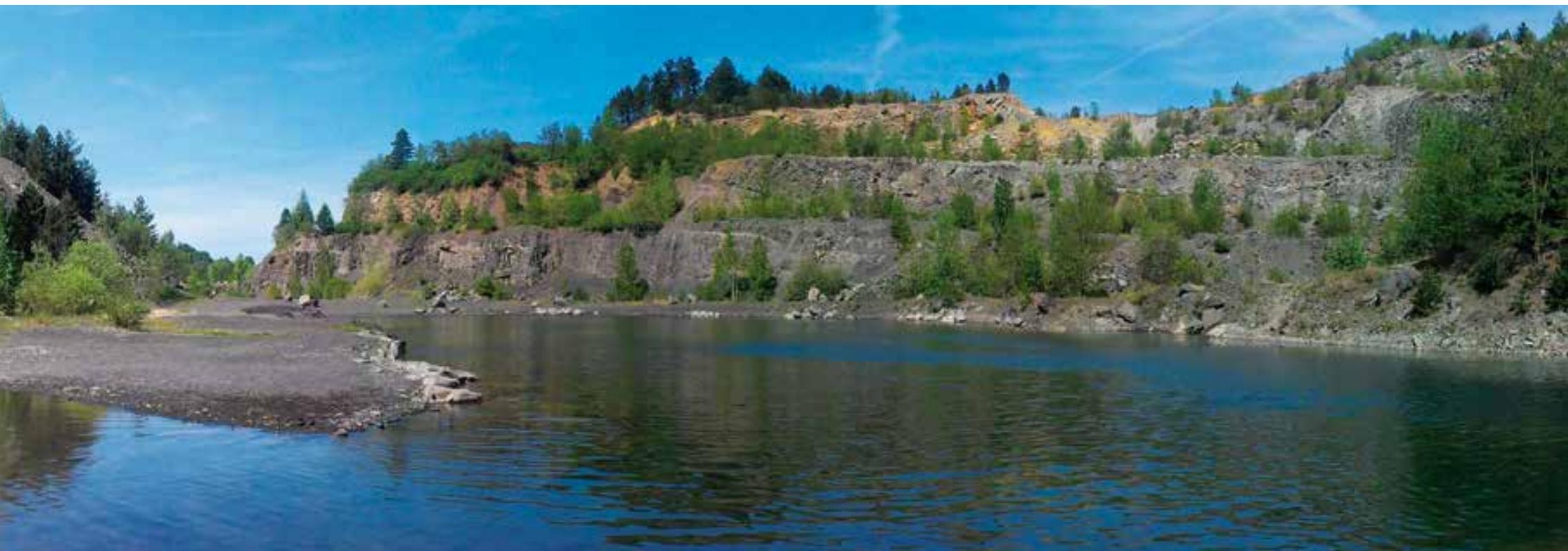




\section{Literatura}

[1] ANSORGE, L. Scénáře budoucích potřeb vody v sektoru veřejných vodovodů. Vodohospodářské technicko-ekonomické informace [online]. 2016, 58(3), 12-20. ISSN 0322-8916. Dostupné z: http://www.vtei.cz/ 2016/06/scenare-budoucich-potreb-vody-v-sektoru-verejnych-vodovodu/

[2] EKOTOXA. Komplexni studie dopadü, zranitelnosti a zdrojů rizik souvisejicich se změnou klimatu v ČR [online]. Praha: Ministerstvo životního prostředí. 2015. Dostupné z: http://www.mzp.cz/cz/ studie_dopadu_zmena_klimatu

[3] BERAN, A. HANEL, M. a NESLÁDKOVÁ, M. Změny hydrologické bilance způsobené vlivem klimatických změn na území Karlovarského kraje. Vodohospodárské technicko-ekonomické informace [online]. 2016, 58(5), 20-25. ISSN 0322-8916, 1805-6555. Dostupné z: http://www.vtei.cz/2016/10/ zmeny-hydrologicke-bilance-zpusobene-vlivem-klimatickych-zmen-na-uzemi-karlovarskeho-kraje/

[4] VLNAS, R. Pozorované změny složek hydrologické bilance z hlediska využitelných vodních zdrojů. Vodohospodářské technicko-ekonomické informace [online]. 2015, 57(4-5), 27-32. ISSN 0322-8916. Dostupné z: http://www.vtei.cz/2015/08/pozorovane-zmeny-slozek-hydrologicke-bilance-z-hlediska-vyuzitelnych-vodnich-zdroju/

[5] BERAN, A. a HANEL, M. Definování zranitelných oblastí z hlediska nedostatku vody na území České republiky. Vodohospodářské technicko-ekonomické informace [online]. 2015, 57(4-5), 23-26. ISSN 03228916.Dostupnéz:http://www.vtei.cz/2015/08/definovani-zranitelnych-oblasti-z-hlediska-nedostatku-vody-na-uzemi-ceske-republiky/

[6] MZE a MŽP. Zprávy o stavu vodního hospodářství České republiky. (Voda, eAGRI) [online]. 2015 [vid. 2015-06-12]. Dostupné z: http://eagri.cz/public/web/mze/voda/osveta-a-publikace/ publikace-a-dokumenty/modre-zpravy/

[7] SMEETS, E. and WETERING, R. Environmental indicators: Typology and overview [online]. 25. Copenhagen: European Environment Agency. 1999. Technical Report. Dostupné z: http://www.eea. europa.eu/publications/TEC25

[8] EEA. Digest of EEA indicators 2014 [online]. Copenhagen: European Environment Agency, 2014. EEA Technical report, 8/2014. ISBN 978-92-9213-459-4. Dostupné z: http://dx.publications.europa. eu/10.2800/17963

[9] ALCAMO, J. Chapter Six The SAS Approach: Combining Qualitative and Quantitative Knowledge in Environmental Scenarios. In: Joseph ALCAMO, ed. Developments in Integrated Environmental Assessment [online]. 2. edition. B.m.: Elsevier, 2008 [vid. 2012-12-03], s. 123-150. ISBN 978-0-444-53293-0. Dostupné z: doi:10.1016/S1574-101X(08)00406-7

[10] ALCAMO, J. Scenarios as tools for international environmental assessments [online]. Copenhagen, Denmark; Luxembourg: European Environment Agency; Office for Official Publications of the European Communities [distributor], 2001. Environmental Issue Report, 24. ISBN 92-9167-402-8. Dostupné z: http://www.eea.europa.eu/publications/environmental_issue_report_2001_24

[11] ANSORGE, L. a ZEMAN, M. Metodika pro stanovení potřeb vody na základě indikátorů hnacích sil potřeby vody [online]. Praha: Výzkumný ústav vodohospodářský T. G. Masaryka, v.v.i., 2015. ISBN 978-80-87402-34-4. Dostupné z: http://heis.vuv.cz/data/webmap/datovesady/projekty/ socioekonomzmenyspotrebavody/dokumenty/download.asp?id=1

[12] ANSORGE, L., DLABAL, J., HANEL, M., KUČERA, J. a kol. Scénáre potréeb vody pro období 2030-50 - Sektory veřejných vodovodů a energetiky: Př́padová studie [online]. Praha: Výzkumný ústav vodohospodářský T. G. Masaryka, v.v.i., 2015. ISBN 978-80-87402-45-0. Dostupné z: http://heis.vuv.cz/data/webmap/ datovesady/projekty/socioekonomzmenyspotrebavody/dokumenty/download.asp?id=3

[13] ANSORGE, L. Hodnocení budoucích potřeb vodnich zdrojů pro zemědělství. Praha, 2016. Disertační práce. ČVUT v Praze, Fakulta stavební.

[14] MPO. Aktualizace Státní energetické koncepce [online]. Praha: Ministerstvo průmyslu a obchodu. 2014. Dostupné z: http://www.mpo.cz/dokument158059.html

[15] MPO. Doplňujici analytický materiál knávrhu aktualizace Státní energetické koncepce [online]. Praha: Ministerstvo průmyslu a obchodu. 2014. Dostupné z: http://www.mpo.cz/dokument158059.html

[16] Čsú. Projekce obyvatelstva České republiky do roku 2100 [online]. Praha: Český statistický úruad. 2013. Dostupné z: http://www.czso.cz/csu/2013edicniplan.nsf/p/4020-13

[17] ČSú. Projekce obyvatelstva $v$ krajích ČR do roku 2050 [online]. Praha: Český statistický úrad. 2014. Dostupné z: www.czso.cz/csu/czso/projekce-obyvatelstva-v-krajich-cr-do-roku-2050-ua08v25hx9

[18] BURCIN, B., ČERMÁK, Z., KUČERA, T. a Š́́DLO, L. Prognóza vývoje počtu obyvatel v krajích České republiky do roku 2065 [online]. 2014. Dostupné z: http://heis.vuv.cz/projekty/TD020113/

[19] UNEP. Options for decoupling economic growth from water use and water pollution: A report of the Water Working Group of the International Resource Panel [online]. B.m.: United Nations Environment Programme, 2015 [vid. 2016-05-17]. ISBN 978-92-807-3534-5. Dostupné z: http://www.unep.org/ resourcepanel/KnowledgeResources/AssessmentAreasReports/Water/tabid/133332/Default.aspx

[20] OTE. Zpráva o očekávané dlouhodobé rovnováze mezi nabídkou a poptávkou elektřiny a plynu 2015 [online]. Praha: OTE a.s. 2016. Dostupné z: http://www.ote-cr.cz/o-spolecnosti/soubory-vyrocnizprava-ote/ZOOR_2014.pdf

[21] OTE. Zprávy o očekávanérovnováze [online].2016. Dostupnéz: http://www.ote-cr.cz/o-spolecnosti/ vyrocni-zpravy

\section{Autoři}

Ing. Libor Ansorge, Ph.D.

凶libor.ansorge@vuv.cz

\section{Ing. Jiří Dlabal}

凶jiri.dlabal@vuv.cz

Výzkumný ústav vodohospodářský T. G. Masaryka, v. v. i.

Příspěvek prošel lektorským řízením.

\section{ESTIMATION OF WATER WITHDRAWALS IN THE CZECH REPUBLIC}

\section{ANSORGE, L.; DLABAL, J.}

TGM Water Research Institute, p. r. i.

Keywords: future water demand - public water systems - energy sector - stock production

The article presents the results of a Project TD020113. This project was focused on the estimation of future water withdrawals in the Czech Republic between 2030 and 2050. We analysed four possible social-economic pathways of the Czech society. We modelled the estimation of withdrawals for public water supply sector and energy sector in the Czech Republic using available demographic prognosis and scenarios published in State Energy Policy of the Czech Republic from 2014. We also modelled water needs for livestock production. Water needs for livestock production was based on statistics of livestock and specific water needs of different livestock species. Unfortunately, there is no clear linkage between water needs for livestock and water withdrawals. Current data in the Czech Republic and the approach based on statistical models do not allow creating a model for irrigation needs. For this reason the agriculture water needs were estimated only. We also did not model the estimation of withdrawals for industry and for other withdrawals. Two scenarios predicted a decrease of water withdrawals for public water supply and two scenarios predicted a stagnation of water withdrawals for this sector between 2030 and 2050 compared with current withdrawals (see Fig. 3). Between 2030 and 2050 a significant decrease of withdrawals for energy sector can be expected. Only the social-economic scenario focused on economic development in combination with the gas scenario of future energy development leads to small increase of water withdrawals for energy sector (see Fig. 4). Table 1 summarizes the estimation of sectoral water withdrawals for four social-economic scenarios. Total water withdrawals were 1.6 billion $\mathrm{m}^{3}$.year ${ }^{-1}$ in the Czech Republic in 2015 (see Fig. 1). The scenario with preference of security tasks (food security, energy security etc.) predicted water withdrawals between 1.389 and 1.583 billion $\mathrm{m}^{3}$.year' ${ }^{1}$. The scenario with preference of economic development predicted water withdrawals between 1.514 and 1.851 billion $\mathrm{m}^{3}$.year ${ }^{-1}$. The scenario with preference of an environmental policy predicted water withdrawals between 1.076 and 1.264 billion $\mathrm{m}^{3}$.year ${ }^{1}$. The scenario with preference of sustainable development

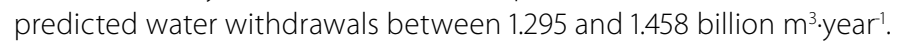

